\title{
Prezydent miasta na prawach powiatu jako zarządca dróg publicznych - na przykładzie Wrocławia
}

\author{
\# droga publiczna \# miasto na prawach powiatu \# Prezydent Wrocławia \# zarządca \# \\ finansowanie \# własność \# dobro publiczne \\ \# public road \# urban country \# mayor of the city of Wrocław \# administrator \# financing \# \\ ownership \# public good
}

Do zarządcy dróg publicznych należy bardzo wiele zadań, o czym świadczy obszerne, otwarte wyliczenie zawarte w art. 20 - art. 20b oraz art. $20 f$ u.d.p. Mając na uwadze wysoki stopień specjalizacji zadań związanych z funkcjonowaniem dróg publicznych, ustawodawca zdecydował się na umożliwienie wykonywania zadań zarządcy drogi przy pomocy jednostki organizacyjnej będącej zarządem drogi. Jednostka taka jest szczególnie pomocna w miastach na prawach powiatu, stanowiących aglomeracje o złożonej infrastrukturze drogowej i komunikacyjnej. Ze względu na przecinanie się dróg różnej kategorii na obszarze miasta na prawach powiatu przewidziano rozwiązanie, zgodnie z którym na jego obszarze zarządcą wszystkich dróg publicznych, z wyjątkiem autostrad i dróg ekspresowych, jest prezydent miasta.

Administrator of public roads is responsible for many task, as evidenced by the extensive, open enumeration included in the article 20 - 20b and 20f of the act on public roads. Bearing in mind the high degree of specialization of tasks related to the functioning of public roads, the legislator decided to allow performing the tasks of the road administrator with the help of an organizational unit being the road management board. This unit is particularly helpful in urban country, which constitute agglomerations with complex road and communication infrastructure. Due to the intersection of roads of various categories within the urban country were predicted solution, whereby the president of the urban city is the manager of all public roads, except for motorways and expressways.

Miasto. Pamięć i Przyszłość 3/2 (2018) ISSN 2543-621X

\section{OPEN ACCESS}

Citation: Majczak P., Prezydent miasta na prawach powiatu jako zarządca dróg publicznych - na przykładzie Wrocławia, „Miasto. Pamięć i Przyszłość", 3/2 (2018)

https://doi.org/10.26774/mpp.84

Editor: Jerzy Korczak

Received: October, 2018

Accepted: December, 2018

Published: December, 2018

Copyright: ๑ Ośrodek „Pamięć i Przyszłość" This is an open access article distributed under the terms of the Creative Commons Attribution-ShareAlike Licence, which permits unrestricted use, distribution, and reproduction in any medium, provided the original author and source are credited, with indications if any changes are made. All derivative works must be licensed under the same licence. 
mgr Paweł Majczak - doktorant w Zakładzie Postępowania Administracyjnego i Sądownictwa Administracyjnego Instytutu Nauk Administracyjnych na Wydziale Prawa, Administracji i Ekonomii Uniwersytetu Wrocławskiego 


\section{Organy miasta na prawach powiatu}

Miasto na prawach powiatu stanowi jednostkę, w której ustawodawca de facto zawarł gminę i powiat. Pod względem ustrojowym jest ono gminą (art. 92 ust. 2 u.s.p.) z tym, że dodatkowo wykonuje zadania powiatu. Do zakresu działania gminy należą wszystkie sprawy publiczne o znaczeniu lokalnym, niezastrzeżone ustawami na rzecz innych podmiotów (art. 6 ust. 1 u.s.g. ${ }^{2}$ ). Do zadań własnych gminy należy zaspokajanie zbiorowych potrzeb wspólnoty, m.in. sprawy gminnych dróg, ulic mostów, placów oraz organizacji ruchu drogowego (art. 7 ust. 1 pkt 2 u.s.g.). Powiat wykonuje określone ustawami zadania publiczne o charakterze ponadgminnym m.in. w zakresie transportu zbiorowego i dróg publicznych (art. 4 ust. 1 pkt 6 u.s.p.). Organami miasta na prawach powiatu są rada powiatu oraz prezydent miasta (art. 92 ust. 1 u.s.p.).

Rada miasta jest organem stanowiącym i kontrolnym (art. 169 ust. 4 Konstytucji RP3). Kompetencje rady miasta obejmują zarówno kompetencje rady gminy (miejskiej)4, jak i rady

Miasto. Pamięć i Przyszłość 3/2 (2018) ISSN 2543-621X powiatu5. Do wyłącznej właściwości rady miasta należą sprawy określone w art. 18 ust. 2 u.s.g. oraz sprawy wynikające $z$ art. 12 u.s.p.

Prezydent miasta na prawach powiatu od dnia 27 października 2002 r. zastąpił zarząd miasta ${ }^{6}$. Łączy w sobie funkcję wójta oraz zarządu i starosty powiatu?. Nie działa w imieniu starosty, a tym bardziej z upoważnienia starosty, lecz jako starostå ${ }^{2}$. Prezydent miasta na prawach powiatu pełni funkcje:

1) monokratycznego organu wykonawczego miasta,

1. Ustawa z dnia 5 czerwca 1998 r. o samorządzie powiatowym (Dz.U. z 2018 r., poz. 995 z późn. zm.).

2. Ustawa z dnia 8 marca 1990 r. o samorządzie gminnym (tekst jedn. Dz.U. z 2018 r., poz. 994 z późn. zm.).

3. Konstytucja Rzeczypospolitej Polskiej z dnia 2 kwietnia 1997 r. (Dz.U. Nr 78, poz. 483 z późn. zm.).

4. Jeżeli siedziba rady gminy znajduje się w mieście położonym na terytorium tej gminy, rada nosi nazwę rady miejskiej (art. 15 ust. 2 u.s.g.)

5. Samorzad powiatu, [w:] Administracja publiczna. Ustrój administracji samorzqdowej, red. B. Szmulik, K. Miaskowska-Daszkiewicz, t. III, Warszawa 2012.

6. Zob. art. 81 pkt 2 ustawy z dnia 20 czerwca 2002 r. o bezpośrednim wyborze wójta, burmistrza i prezydenta miasta (Dz.U. Nr 113, poz. 984).

7. Samorzad powiatu...

8. Wyrok WSA w Warszawie z dnia 17 listopada 2004 r., II SA 4216/03 (LEX nr 164703). 
2) kierownika urzędu wykonującego uprawnienia zwierzchnika służbowego w stosunku do pracowników urzędu oraz kierowników miejskich jednostek organizacyjnych,

3) zwierzchnika służbowego w odniesieniu do służb, inspekcji i straży,

4) organu wydającego decyzje w indywidualnych sprawach z zakresu administracji publicznej9 (np. w sprawach zezwolenia na zajęcie pasa drogowego i lokalizację lub przebudowę zjazdu - art. 40 ust. 1 i art. 29 ust. 1 u.d. $\left.p^{10}\right)$.

Organ ten został wyposażony zarówno w kompetencje wykonywane samodzielnie i we własnym imieniu11, jak i kompetencje wykonywane w imieniu miasta na prawach powiatu.

\section{Drogi publiczne - pojęcie i kategorie}

Zgodnie z przepisami drogi publiczne ze względu na kryterium własności to stanowiące własność Skarbu Państwa drogi krajowe, a także

9. J. Michalska, Miasto na prawach powiatu - specyficzne połaczenie gminy i powiatu, [w:] Województwo - region - regionalizacja 15 lat po reformie terytorialnej i administracji. II Wydziałowa Konferencja Kół Naukowych Wydziału Prawa, Administracji i Ekonomii Uniwersytetu Wrocławskiego, Wrocław, 21 - 22 listopada 2013 r., red. J. Korczak, Wrocław 2013, s. 144.

10. Ustawa z dnia 21 marca 1985 r. o drogach publicznych (Dz.U. z 2017 r., poz. 2222 z późn. zm.)

11. Tytułem przykładu - prezydent miasta na prawach powiatu, działający jako starosta w postępowaniach administracyjnych zmierzających do wydania decyzji o zezwoleniu na realizację inwestycji drogowej, działa jako organ administracji publicznej, a nie jako organ reprezentujący miasto-gminę jako osobę prawną wyrok WSA w Kielcach z dnia 16 czerwca 2011 r., II SA/Ke 247/11 (LEX nr 852148).

12. Ustawa z dnia 20 czerwca 1997 r. - Prawo o ruchu drogowym (Dz.U. z 2017 r., poz. 1260 z późn. zm.).

13. Zob. Prawo administracyjne, red. J. Boć, Wrocław 2003, s. 292; I. Sierpowska, Drogi publiczne jako kategoria dobra publicznego - w świetle pog/ądów doktryny i rozwiq̨zá normatywnych, http:// www.bibliotekacyfrowa.pl/Content/34405/0020.pdf [dostęp: 21.05.2018]. stanowiące własność właściwego samorządu województwa, powiatu i gminy odpowiednio drogi wojewódzkie, powiatowe i gminne. Drogi wewnętrzne, o których mowa w art. 8 u.d.p., a contrario nie stanowiąc własności Skarbu Państwa ani samorządowej, drogami publicznymi nie są. Dokonując analizy systemowej przepisów regulujących kwestie prawa drogowego, należy zanalizować porównawczo pojęcia „droga” oraz „droga publiczna”. Droga to, według art. 2 pkt 1 p.r.d., „wydzielony pas terenu składający się z jezdni, pobocza, chodnika, drogi dla pieszych lub drogi dla rowerów, łącznie z torowiskiem pojazdów szynowych znajdującym się w obrębie tego pasa, przeznaczony do ruchu lub postoju pojazdów, ruchu pieszych, jazdy wierzchem lub pędzenia zwierząt" 12. To samo pojęcie zostało zdefiniowane także w art. 4 pkt 2 u.d.p., zgodnie z którym droga to „budowla wraz z drogowymi obiektami inżynierskimi, urządzeniami oraz instalacjami, stanowiąca całość techniczno-użytkową, przeznaczona do prowadzenia ruchu drogowego, zlokalizowana w pasie drogowym". Nazwa "droga” tyczy się w przeważającej mierze komunikacji, nie każda "droga” jest jednak „drogą publiczną".

Zasadą jest, że z drogi publicznej mogą korzystać wszyscy. Jest to zatem pierwsza materialna cecha odróżniająca pojęcie „droga publiczna” od pojęcia „droga”. Drogi publiczne zaliczane są do kategorii dobra publicznego wytworzonego, do obiektów użyteczności publicznej13. Twierdzenie o powszechności dostępu do dróg publicznych wynika expressis verbis z treści

Miasto. Pamięć i Przyszłość 3/2 (2018) ISSN 2543-621X 
art. 1 u.d.p. w brzmieniu: „Drogą publiczną jest droga zaliczona na podstawie niniejszej ustawy do jednej z kategorii dróg, z której może korzystać każdy, zgodnie z jej przeznaczeniem...". Przepisy szczególne i u.d.p. wprowadzają jednak ograniczenia w tym zakresie.

Drugim podstawowym wyróżnikiem (formalnym) "drogi publicznej” jest zaliczenie "drogi” do ustawowo określonej kategorii. Przedstawione twierdzenia zostały niejednokrotnie poparte przez orzecznictwo sądowe, w którym dokonano syntezy rozważań teoretycznych w następującej postaci: „Nie każda droga spełniająca funkcję ciągu komunikacyjnego może być uznana za drogę publiczną. By zyskała taki status, musi zostać zaliczona w trybie przewidzianym ustawą o drogach publicznych do jednej z kategorii dróg wymienionych w art. 2 ust. 1 pkt 1-4 tej ustawy i jednocześnie spełniać warunek możliwości powszechnego korzystania z niej"14. Wyróżnia się cztery kategorie dróg publicznych - krajowe, wojewódzkie, powiatowe i gminne. Formy zaliczenia drogi do odpowiedniej kategorii obejmują rozporządzenia, w przypadku dróg krajowych (art. 5 u.d.p.), oraz uchwały organów stanowiących jednostek samorządu terytorialnego we współdziałaniu z właściwymi organami - w odniesieniu do dróg wojewódzkich, powiatowych oraz gminnych (art. 6 - art. 7 u.d.p.). W kontekście miast na prawach powiatu należy zwrócić uwagę na treść art. 6a ust. 2 u.d.p., zgodnie z którym: „Zaliczenie drogi do kategorii dróg powiatowych następuje w drodze uchwały rady powiatu w porozumieniu

Miasto. Pamięći Przyszłość 3/2 (2018) ISSN 2543-621X 131 z zarządem województwa, po zasięgnięciu opinii wójtów (burmistrzów, prezydentów miast) gmin, na obszarze których przebiega droga, oraz zarządów sąsiednich powiatów, a w miastach na prawach powiatu - opinii prezydentów miast". Uwzględniając art. 92 ust. 1 u.s.p., zgodnie z którym funkcje organów powiatu w miastach na prawach powiatu sprawuje rada miasta i prezydent miasta, należy stwierdzić, że w mieście na prawach powiatu kompetencja do zaliczenia drogi do kategorii dróg powiatowych należy do rady miasta15. Przepis art. 6 a ust. 2 u.d.p. stanowi o obowiązku zasięgnięcia opinii m.in. wójtów (burmistrzów, prezydentów miast) gmin, na obszarze których przebiega droga. Ten obowiązek współdziałania w miastach na prawach powiatu nie jest realizowany, rada miasta musiałaby bowiem zasięgać opinii prezydenta miasta. Należy zauważyć, że przepis art. 6a u.d.p. - w przypadku miast na prawach powiatu - raczej nie będzie miał praktycznego zastosowania, a to dlatego, że nie będą spełnione warunki w nim opisane.

Zgodnie z art. 6a ust. 1 u.d.p. drogi powiatowe stanowią połączenia miast będących siedzibami powiatów z siedzibami gmin i siedzib gmin między sobą. W obrębie miasta na prawach powiatu nie ma wyodrębnionych gmin (miasto na prawach powiatu samo jest gminą) ani powiatów. Drogi gminne i powiatowe przebiegające przez miasto na prawach powiatu to de facto drogi miejskie zarządzane przez prezydenta miasta (organ miasta na prawach powiatu) i finansowane z budżetu miasta na prawach powiatu. Dyspozycja art. 6a ust. 1 u.d.p.

14. Wyrok WSA w Warszawie z dnia 27 czerwca 2008 r., I SA/Wa 383/08 (Legalis nr 163964).

15. Zob. wyrok WSA w Gliwicach z dnia 29 czerwca 2015 r., II SA/ Gl 1528/14 (LEX nr 1790086). 
nie pozwala na nadanie drodze w mieście na prawach powiatu kategorii drogi powiatowej. Droga może stać się drogą powiatową zasadniczo w czterech sytuacjach. Po pierwsze, nowo wybudowany odcinek drogi zostaje zaliczony do kategorii drogi, w której ciągu leży (art. 10 ust. 4 u.d.p.). Następuje to z mocy prawa, więc zastosowania nie mają art. 6 i 7 u.d.p. Po drugie, do kategorii drogi powiatowej zostaje zaliczony odcinek drogi wojewódzkiej zastąpiony nowo wybudowanym odcinkiem drogi (art. 10 ust. 5e u.d.p.), co również następuje z mocy prawa, więc zastosowania nie mają art. 6 i 7 u.d.p. Po trzecie, na skutek pozbawienia kategorii drogi wojewódzkiej w trybie opisanym w art. 10 ust. 5a u.d.p, który nie odsyła do stosowania art. 6 i 7 u.d.p. Po czwarte, droga może stać drogą powiatową w wyniku przekwalifikowania innej kategorii drogi na drogę powiatową, najczęściej w rezultacie zmiany kategorii z drogi gminnej na drogę powiatową albo w wyniku deklasyfikacji drogi wojewódzkiej na drogę powiatową. W ostatniej (czwartej) sytuacji ma zastosowanie art. 6a w zw. z art. 10 ust. 1-3 u.d.p. Wówczas uchwała rady miasta, oparta na art. 6a ust. 2 u.d.p. - w przypadku zaliczenia odcinka drogi znajdującego się w obszarze miasta na prawach powiatu do kategorii dróg powiatowych, powinna zostać podjęta w porozumieniu z zarządem województwa oraz po zasięgnięciu opinii zarządów sąsiednich powiatów czy

16. Wyrok WSA w Gliwicach z dnia 30 października 2008 r., II SA/G| 498/08 (LEX nr 491249).

17. Zob. rozstrzygnięcie nadzorcze nr P-II.4131.2.69.2016 Wojewody Podkarpackiego z dnia 19 kwietnia 2016 r., http://edziennik. rzeszow.uw.gov.pl/WDU_R/2016/1419/oryginal/Printable.html [dostęp: 21.05.2018].

18. Wyrok NSA z dnia 4 kwietnia 2008 r., II OSK 102/08 (LEX $n r$ 453213). prezydentów miast, w przypadku miast na prawach powiatów ${ }^{16}$.

Opinia nie jest wiążąca, ale ma być pomocna w procesie decyzyjnym. Niezasięgnięcie opinii przed podjęciem uchwały stanowi istotne naruszenie przepisów u.d.p.77, co może skutkować wyeliminowaniem uchwały z obrotu prawnego. Odnosząc treść art. 6a ust. 3 u.d.p. do miast na prawach powiatu, należy uznać analogicznie, że jeżeli miałby on zastosowanie, to rada miasta (zamiast rady powiatu) nie będzie zasięgała opinii prezydenta miasta. Do rady miasta należy również zaliczenie drogi do kategorii dróg gminnych i wtedy także nie zasięga się opinii prezydenta miasta (art. 7 ust. 2 u.d.p.).

W miastach na prawach powiatu ustalenie przebiegu istniejących dróg gminnych następuje w drodze uchwały rady miasta (art. 7 ust. 3 u.d.p.). Uchwała organu stanowiącego samorządu terytorialnego w przedmiocie ustalenia kategorii drogi publicznej stanowi akt prawa miejscowego ${ }^{18}$. Prezydent miasta na prawach powiatu jest organem współdziałającym w sprawach ustalenia przebiegu istniejących dróg krajowych w celu zapewnienia ciągłości dróg krajowych (art. 5 ust. 3 u.d.p.), w sprawach ustalenia przebiegu istniejących dróg wojewódzkich (art. 6 ust. 3 u.d.p.), w sprawach zaliczenia drogi do kategorii dróg powiatowych (art. 6a ust. 2 in fine u.d.p.). Do nadania drodze odpowiedniej kategorii niezbędne jest wcześniejsze zakończenie i odebranie robót budowlanych, a także otrzymanie pozwolenia na użytkowanie.

Miasto. Pamięć i Przyszłość 3/2 (2018) ISSN 2543-621X 


\section{Nieruchomości drogowe}

W zakresie własności nieruchomości drogowych kluczowe znaczenie ma art. za u.d.p. Jak już ustalono, w zależności od rodzaju dróg, nieruchomości drogowe stanowią własność Skarbu Państwa (drogi krajowe) albo własność właściwego samorządu województwa, powiatu, gminy (drogi wojewódzkie, powiatowe i gminne).

Droga jest częścią składową nieruchomości gruntowej ze względu na jej trwałe związanie z gruntem. Zgodnie z treścią art. 47 § 1 k.c. ${ }^{19}$, "część składowa rzeczy nie może być odrębnym przedmiotem własności i innych praw rzeczowych". Przepis art. 48 k.c., stanowiący lex specialis w stosunku do art. 47 k.C., określając otwarty katalog części składowych gruntu, wymienia m.in. inne urządzenia trwale związane z gruntem. W celu określenia, czym są inne urządzenia, należy odwołać się do definicji budowli (art. 3 pkt 3 pr. bud. ${ }^{20}$ ). Warto w tym miejscu zaznaczyć, że "droga" jest w rozumieniu prawa budowlanego budowlą nieobejmującą gruntu, na którym się znajduje ${ }^{21}$. Analiza taka prowadzi do podsumowania, że właścicielem poszczególnych kategorii dróg jest właściciel nieruchomości zabudowanej drogą publiczną, zatem aby mógł zostać wydany akt o zaliczeniu danej drogi do kategorii drogi publicznej, niezbędne jest, aby Skarb Państwa albo jednostka samorządu terytorialnego dysponowały prawem własności do nieruchomości zabudowanej taką drogą ${ }^{22}$. Uwzględniając szczególny status miast na prawach powiatu, skoro w świetle art. 92 ust. 2 u.s.p. "(m)iasto na prawach powiatu jest gminą wykonującą

Miasto. Pamięć i Przyszłość 3/2 (2018) ISSN 2543-621X zadania powiatu na zasadach określonych w tej ustawie", należy stwierdzić, że drogi stanowiące własność miasta na prawach powiatu są zarazem drogami stanowiącymi mienie gminy ${ }^{23}$.

Kwestie wywłaszczeń terenów po drogi publiczne reguluje ustawa z dnia 10 kwietnia 2003 r. o szczególnych zasadach przygotowania i realizacji inwestycji w zakresie dróg publicznych ${ }^{24}$. Zgodnie z art. 11a ust. 1 u.i.d., "(w)ojewoda w odniesieniu do dróg krajowych i wojewódzkich albo wykonujący zadania zlecone z zakresu administracji rządowej starosta w odniesieniu do dróg powiatowych i gminnych, wydają decyzję o zezwoleniu na realizację inwestycji drogowej na wniosek właściwego zarządcy drogi". Na tle tego przepisu powstała wątpliwość, czy dopuszczalne jest, aby prezydent miasta na prawach powiatu, pełniący funkcje i wykonujący zadania starosty, będący zarządcą m.in. dróg gminnych i powiatowych, działałjednocześnie jako organ administracji publicznej prowadzący postępowanie w sprawie lokalizacji dróg powiatowych i gminnych oraz jako wnioskodawca (zarządca dróg gminnych i powiatowych). W następstwie wydanej decyzji właścicielem nieruchomości staje się przecież gmina, a organem orzekającym w tej sprawie jej organ - prezydent miasta.

19. Ustawa z dnia 23 kwietnia 1964 r. - Kodeks cywilny (Dz.U. z 2018 r., poz. 1025 z późn. zm.).

20. Ustawa z dnia 7 lipca 1994 r. - Prawo budowlane (Dz.U. z 2018 r., poz. 1202 z późn. zm.).

21. T. Woś, Wywłaszczenie nieruchomości i ich zwrot, Warszawa 2011, s. 95.

22. W. Maciejko, P. Zaborniak, Ustawa o drogach publicznych. Komentarz, Warszawa 2010, s. 54.

23. Zob. wyrok WSA w Gliwicach z dnia 29 czerwca 2015 r., II SA/ Gl 1528/14 (LEX nr 1790086).

24. Dz.U. z 2017 r., poz. 1496 z późn. zm., zwana dalej w skrócie u.i.d. 
Zgodnie ze stanowiskiem sądów administracyjnych i przedstawicieli doktryny, nie zachodzi konieczność wyłączenia prezydenta miasta na prawach powiatu z orzekania w sprawach wydania zezwolenia na realizację inwestycji drogowej25. Prezydent miasta na prawach powiatu (jako zarządca m.in. dróg gminnych i powiatowych) nie składa jednak wniosku sam do siebie (jako organu pełniącego funkcje i wykonującego zadania starosty). Jeżeli przepis prawa przypisuje organowi administracji publicznej kompetencję do wydania decyzji i złożenia wniosku o wszczęcie postępowania, postępowanie wszczynane jest z urzędu ${ }^{26}$.

Kwestie własności dróg publicznych są bardzo istotne, choćby z powodów merkantylnych, bo z treści art. 3 ust. 1 i 2 ustawy z dnia 16 grudnia 2005 r. o finansowaniu infrastruktury transportu lądowego ${ }^{27}$ można wyprowadzić zasadę, zgodnie z którą podstawowe zadania w zakresie dróg finansowane są przez ich właścicieli. W granicach miast na prawach powiatu zadania w zakresie finansowania, budowy, przebudowy, remontu, utrzymania, ochrony i zarządzania drogami publicznymi, z wyjątkiem autostrad i dróg ekspresowych, finansowane są z budżetów tych miast (art. 3 ust. 3 u.f.i.t.l.).

25. Wyrok WSA w Olsztynie z dnia 16 czerwca 2011 r., II SA/OI 299/11 (LEX nr 852150). Zob. T. Woś, Zezwolenie na realizację inwestycji drogowej w specustawie drogowej - aspekty proceduralne, „Przegląd Prawa Publicznego" 2009, nr 11, s. 6 - 25.

26. Wyrok NSA z dnia 30 marca 2010 r., II OSK 88/10 (LEX $\mathrm{nr}$ 597931).

27. Ustawa z dnia 16 grudnia 2005 r. o finansowaniu infrastruktury transportu lądowego (Dz.U. z 2018 r. poz. 203), dalej w skrócie u.f.i.t.l.

28. Ustawa z dnia 27 marca 2003 r. o planowaniu i zagospodarowaniu przestrzennym (Dz.U. z 2017 r., poz. 1073 z późn. zm.).

29. Zob. wyrok NSA z dnia 9 lipca 2013 r., II OSK 609/12 (LEX nr 1369032).

\section{Zarządca drogi jako organ administracji publicznej}

Termin „zarządca drogi” nie został zdefiniowany w słowniczku ustawowym i jest o nim mowa dopiero w art. 19 u.d.p. Jak określa art. 19 ust. 2 u.d.p., zarządcami dróg są - co do zasady Generalny Dyrektor Dróg Krajowych i Autostrad (dla dróg krajowych) oraz organy wykonawcze wszystkich trzech typów jednostek samorządu terytorialnego. Sytuacja wyjątkowa dotyczy kompetencji organu dla dróg znajdujących się w granicach miasta na prawach powiatu - w tym przypadku zarządcą dróg gminnych, powiatowych, wojewódzkich oraz krajowych (z wyjątkiem autostrad i dróg ekspresowych) jest prezydent miasta na prawach powiatu.

Rozwiązanie takie wydaje się być słuszne przede wszystkim ze względu na uproszczenie procedur planistycznych. Stosownie do art. 53 ust. 4 pkt 9 u.p.z.p.. ${ }^{28}$, decyzje w sprawach ustalenia inwestycji celu publicznego o znaczeniu powiatowym lub gminnym wydaje wójt, burmistrz, prezydent miasta, po uzgodnieniu z właściwym zarządcą drogi - w odniesieniu do obszarów przyległych do pasa drogowego. Wynika z tego, że prezydent miasta na prawach powiatu powinien dokonać uzgodnień sam ze sobą (jako zarządcą dróg na terenie miasta na prawach powiatu). Jest to jednak niedopuszczalne, bowiem w przypadku, gdy organ rozstrzygający sprawę oraz organ współdziałający to jeden i ten sam organ, brak jest potrzeby dokonania uzgodnienia29. Nie można także zakładać, że w urzędzie prezydenta jest wiele wydziałów, między

Miasto. Pamięć i Przyszłość 3/2 (2018) ISSN 2543-621X 
którymi mogłyby następować takie uzgodnienia. Mnożenie czynności w ten sposób naruszałoby przepisy, a także założenia sprawnego i szybkiego działania administracji publicznej. Prezydent miasta na prawach powiatu nie dokonuje więc uzgodnienia w sprawach ustalenia inwestycji celu publicznego o znaczeniu powiatowym lub gminnym, co stanowi uproszczenie procedur. Analogicznie należy rozpatrywać procedurę przygotowywania projektu miejscowego planu zagospodarowania przestrzennego (art. 17 pkt 6 lit. b tiret 3 u.p.z.p.). Ustawodawca nie zdecydował się na przyznanie prezydentowi miasta na prawach powiatu kompetencji zarządcy drogi w odniesieniu do dróg o najwyższym priorytecie, tj. ekspresowych i autostrad, pozostawiając je w zarządzie Generalnego Dyrektora Dróg Krajowych i Autostrad. Ze względu na złożoną strukturę dróg na obszarach obejmujących np. jedną miejscowość, w której przecinają się drogi zarówno krajowe, wojewódzkie, powiatowe, jak i gminne, zdecydowano się na wprowadzenie rozwiązania znanego strukturom administracyjnym od dawna, mianowicie na możliwość zawierania porozumień między zarządcami dróg. Ma ono także służyć przejmowaniu zadań przez zarządców samorządowych (art. 19 ust. 4 u.d.p.).

Do właściwości zarządcy drogi należą sprawy z zakresu planowania, budowy, przebudowy, remontu, utrzymania i ochrony dróg (art. 19 ust. 1 u.d.p.). Otwarty katalog zadań zarządcy drogi przedstawiają art. 20, art. 20a, art. 20b i $20 f$ u.d.p. Wprawdzie normy u.d.p. nie zawierają pełnego wykazu spraw należących do

Miasto. Pamięć i Przyszłość 3/2 (2018) ISSN 2543-621X 135 zarządcy drogi publicznej, jednak wykładnia norm zadaniowych powinna odbywać się przy uwzględnieniu kierunku wyznaczonego ogólnymi kompetencjamiº.

Do zarządzania drogami nie został utworzony nowy organ administracji publicznej. Nie oznacza to, że zarządca drogi musi wykonywać zadania osobiście. Istnieje możliwość utworzenia pomocniczej, wyspecjalizowanej jednostki organizacyjnej - zarządu drogi w formie uchwały właściwej jednostki samorządu terytorialnej albo ustawy. W mieście na prawach powiatu uchwałę taką może podjąć rada miasta. W ramach pełnomocnictwa administracyjnego istnieje również możliwość upoważnienia przez zarządcę drogi pracowników urzędu zarządcy drogi (jeżeli wykonuje on swoje zadania osobiście) albo pracowników zarządu drogi, jeżeli taki organ został utworzony do załatwiania spraw w imieniu zarządcy. Taka delegacja może nastąpić w ustalonym zakresie, obejmującym zwłaszcza wydawanie decyzji administracyjnych, co zostało wyrażone w art. 21 ust. 1 a u.d.p. i jest zgodne $z$ art. 268a k.p.a31. Przekazanie zadań zarządcy drogi następuje dopiero z chwilą udzielenia pracownikom upoważnienia do prowadzenia spraw obejmujących swym zakresem zadania administracji drogowej, a nie w momencie utworzenia zarządu dróg samorządowych. Samo utworzenie urzędu skutkuje przede wszystkim wykreowaniem struktury, natomiast aby mogła ona pełnić dane funkcje, niezbędne jest podjęcie odrębnego aktu.

30. Wyrok NSA z dnia 1 marca 2017 r., II OSK 2813/16 (LEX nr 2283252).

31. Ustawa z dnia 14 czerwca 1960 r. - Kodeks postępowania administracyjnego (Dz.U. z 2017 r., poz. 1257 z późn. zm.). 
Zarówno utworzenie zarządu drogi, jak i dekoncentracja wewnętrzna nie skutkują utratą ustawowych kompetencji zarządcy drogi wynikających z u.d.p. Czynności nieprzekraczające obrębu upoważnienia należą do zadań zarządcy drogi. Zarządom dróg przyznano kompetencje uprawniające ich pracowników do wstępu na grunty przyległe do pasa drogowego, z zastrzeżeniem, że musi być to konieczne do wykonywania czynności związanych z utrzymaniem i ochroną dróg, „urządzania czasowego przejazdu przez grunty przyległe do pasa drogowego w razie przerwy w komunikacji na drodze”, a także „ustawiania na gruntach przyległych do pasa drogowego zasłon przeciwśnieżnych" (art. 21 ust. 2 u.d.p.). Jeżeli w wyniku wymienionych działań zarządcy drogi właściciel lub użytkownik gruntu poniesie szkody, przysługuje im odszkodowanie, którego warunki zostały uregulowane w przepisach o gospodarce nieruchomościami. Zarząd drogi nie jest organem administracji publicznej, lecz jednostką organizacyjną powołaną do obsługi takiego organu administracji, którym zawsze pozostaje zarządca drogi. Jeżeli akty administracyjne są wydawane przez pracownika zarządu drogi, to też są to akty zarządcy drogi, gdyż pracownicy ci, wydając takie akty działają w imieniu zarządcy, a nie własnym jako odrębne od zarządcy organy administracji32.

32. Wyrok NSA z dnia 9 lipca 2013 r., II OSK 609/12, LEX nr 1369032.

33. Uchwała Nr LIV/1568/10 Rady Miejskiej Wrocławia z dnia 9 września 2010 r. w sprawie nadania statutu Zarządowi Dróg i Utrzymania Miasta we Wrocławiu (Dz. Urz. Woj. Dolno. z 2010 r. Nr 189, poz. 2832 z późn. zm.).

34. Dane na dzień 31 grudnia 2017 r. - http://www.zdium.wroc.pl/ kategoria/infrastruktura/drogi/ [dostęp: 20.05.2018].

\section{Zarząd drogi - na przykładzie Wrocławia}

We Wrocławiu, uchwałą Rady Miasta z dnia 9 września 2010 r.33, nadano statut Zarządowi Dróg i Utrzymania Miasta we Wrocławiu (ZDiUM). ZDiUM jest jednostką organizacyjną Gminy Wrocław nieposiadającą osobowości prawnej, działającą w formie jednostki budżetowej. Siedziba Zarządu znajduje się we Wrocławiu przy ul. Długiej 49. Swoją działalnością obejmuje obszar miasta Wrocławia. Zarządza mieniem, które jest mieniem gminnym. Prezydent Wrocławia zatrudnia i zwalnia Dyrektora Zarządu, kierującego działalnością ZDiUM jednoosobowo w zakresie pełnomocnictwa udzielonego przez Prezydenta Wrocławia. Dyrektor ZDiUM upoważniony jest do udzielania pracownikom Zarządu upoważnień do reprezentowania Zarządu, w zakresie wynikającym z pełnomocnictwa udzielonego jemu samemu przez Prezydenta Wrocławia. W tym zakresie Dyrektor ZDiUM upoważniony jest również do udzielania pełnomocnictw osobom trzecim. Prezydent Wrocławia jest również organem sprawującym kontrolę nad Zarządem oraz kontrolę prawidłowości rozliczeń Zarządu z budżetem Gminy Wrocław.

ZDiuM zarządza siecią 1069,07km dróg publicznych we Wrocławiu34 o łącznej powierzchni 8761,67 tys. m². Drogi krajowe mierzą 56,46 km długości oraz stanowią powierzchnię 994,59 tys. m². Drogi wojewódzkie to 70,39 km długości i 589,20 tys. $\mathrm{m}^{2}$ powierzchni. Drogi powiatowe 48,30 km długości i 409,67 tys. m² powierzchni, drogi gminne 893,92 km długości i 6768,21 tys.

Miasto. Pamięć i Przyszłość 3/2 (2018) ISSN 2543-621X 
m² powierzchni. ZDiUM zarządza również częścią dróg wewnętrznych we Wrocławiu o łącznej długości 556,58km i powierzchni 4706,78 tys. m².

Przedmiot działania ZDiUM obejmuje działalność podstawową oraz pozostałą. Do pierwszej zalicza się zarządzanie drogami publicznymi i przekazanymi drogami wewnętrznymi, miejscami wyznaczonymi na postój pojazdów samochodowych w strefie płatnego parkowania oraz kanałami technologicznymi. Szczegółowe wyliczenie zadań ZDiUM zawiera § 2 Statutu ZDiUM 35 .

Zarząd Dróg i Utrzymania Miasta we Wrocławiu współpracuje z wieloma podmiotami. Tytułem przykładu - w ostatnim czasie we Wrocławiu kładzie się coraz większy nacisk na odwrócenie skutków polityki prosamochodowej, którą miasto prowadziło od lat 70. XX w. Aglomeracja wrocławska ciągle się rozrasta, co sprawia, że udział samochodów indywidualnych w podróżach po mieście jest na chwilę obecną zbyt wysoki. Konsekwencją tego są korki w mieście. Dlatego też ZDiUM, we współpracy z Biurem Zrównoważonej Mobilności Urzędu Miejskiego Wrocławia, realizuje zadania w zakresie wypracowania zasad i sposobu egzekwowania od inwestorów zakresu rozbudowy układu komunikacyjnego na potrzeby nowych inwestycji w zgodzie z ideą zrównoważonej mobilności36. Dla opracowania projektów planów rozwoju sieci drogowej przydatna jest również współpraca z uczelniami37 prowadzącymi badania naukowe zarówno w sferze technicznej, jak i dotyczące zagospodarowania przestrzennego i innych dziedzin.

Miasto. Pamięć i Przyszłość 3/2 (2018) ISSN 2543-621X

\section{Własność warstwowa}

Z punktu widzenia nieruchomości drogowych newralgiczne znaczenie miałoby unormowanie z zakresu tzw. własności warstwowej, tzn. takiej, która przewidywałaby prawo własności obiektów znajdujących się jedne pod drugimi. Brak takiej regulacji negatywnie odbija się na szeroko rozumianej gospodarce, ze względu na utrudnienia związane z inwestycjami w miejsca, w których występują tunele, wiadukty itp. W obecnym stanie prawnym brakuje możliwości realizacji warstwowo kilku niezależnych inwestycji, ze względu na nieuwzględnienie postrzegania nieruchomości trójwymiarowo, w oderwaniu od gruntu.

Na podstawie dawnego brzmienia art. 14 ust. 1 u.i.d., "Nieruchomości przeznaczone na pasy drogowe, stanowiące własność jednostek samorządu terytorialnego, stają się własnością Skarbu Państwa z dniem, w którym decyzja o ustaleniu lokalizacji drogi dotycząca tych nieruchomości stała się ostateczna". Na skutek rozwoju sieci dróg w Polsce powstaje coraz więcej dróg ekspresowych i autostrad. Charakterystyczne dla nich jest posiadanie wielopoziomowego skrzyżowania z przecinającymi je drogami transportu lądowego i wodnego (art. 4 pkt 10 lit. b i pkt 11

35. Załącznik do uchwały nr XXXII/742/12 Rady Miejskiej Wrocławia z dnia 18 października 2012 r. w sprawie nadania statutu Zarządowi Dróg i Utrzymania Miasta we Wrocławiu, http://bip.zdium. wroc.pl/statut-zdium/ [dostęp: 21.05.2018].

36. http://bip.um.wroc.pl/artykul/672/26002/biuro-zrownowazonej-mobilnosci [dostęp: 21.05.2018].

37. Tytułem egzemplifikacji, na Politechnice Wrocławskiej organizowane są m.in. konferencje z cyklu: „Transport i mobilność w aglomeracji wrocławskiej", na której spotykają się przedstawiciele władz miejskich, pracownicy naukowi oraz zainteresowani mieszkańcy Wrocławia. Ostatnie spotkania dotyczące komunikacji we Wrocławiu i komunikacji w aglomeracji wrocławskiej odbyły się w dniach 15 i 16 maja 2018 r. 
lit. b u.d.p.). Ze względu na nieistnienie w polskim prawie własności warstwowej, nie ma możliwości, aby np. własność nieruchomości, w obrębie której położona jest droga ekspresowa przebiegająca nad lub pod drogą gminną, należała do podmiotów innych niż Skarb Państwa. Z tego względu, własność takiej nieruchomości przechodziła na Skarb Państwa na podstawie art. 14 ust. 1 u.i.d. Konkludując, należy stwierdzić, że prawo własności gruntu w granicach drogi ekspresowej/ autostrady będzie należało do Skarbu Państwa, zatem fragment terenu pasa drogowego drogi gminnej, powiatowej czy wojewódzkiej będzie położony na terenie należącym do Skarbu Państwa. Zarządcą drogi gminnej, powiatowej czy wojewódzkiej pozostanie jednak odpowiednio wójt (burmistrz, prezydent miasta), zarząd powiatu, zarząd województwa. W granicach miast na prawach powiatu zarządcą wszystkich dróg publicznych, z wyjątkiem autostrad i dróg ekspresowych, jest prezydent miasta (art. 19 ust. 5 u.d.p.).

Mogłoby się wydawać, że takie rozwiązanie w miastach na prawach powiatu wyłączy ryzyko zajścia sporu kompetencyjnego. Nic bardziej mylnego. Do sporu kompetencyjnego między prezydentem miasta na prawach powiatu a Generalnym Dyrektorem Dróg Krajowych i Autostrad $^{38}$ może dojść w sprawach dotyczących obszaru znajdującego się na terenie miasta na prawach powiatu, gdzie droga ekspresowa/autostrada krzyżuje się przestrzennie z inną kategorią drogi. Opisaną sytuację można spotkać we Wrocławiu, np. w miejscach przecięcia się Autostradowej Obwodnicy Wrocławia - autostrady
A8 - z drogami innymi niż ekspresowe lub autostrady ${ }^{39}$. O ile wątpliwości nie budzi, że właścicielem gruntu w tych miejscach jest Skarb Państwa, to komplikacje pojawiają się w momencie określenia właściwości zarządcy drogi. Można to wyjaśnić na przykładzie spraw z zakresu zezwolenia na zajęcie pasa drogowego.

Zajęcie pasa drogowego na cele niezwiązane z budową, przebudową, remontem, utrzymaniem i ochroną dróg, co do zasady wymaga zezwolenia zarządcy drogi (art. 40 ust. 1 u.d.p.). Za bezprawne zajęcie pasa drogowego zarządca drogi wymierza administracyjną karę pieniężną (art. 40 ust. 12 u.d.p.). W mieście na prawach powiatu, w miejscu przecinania się drogi ekspresowej/autostrady z drogą inną niż droga ekspresowa/autostrada, zarządcą drogi jest Generalny Dyrektor Dróg Krajowych i Autostrad oraz prezydent miasta. Niedopuszczalne jest przyjęcie, że w sprawie zezwolenia/kary za zajęcie pasa drogowego właściwi są obydwaj zarządcy dróg. Choćby ze względu na fakt, że skutkowałoby to koniecznością wydania dwóch zezwoleń na zajęcie pasa drogowego i dwukrotnego pobrania opłaty. Analogicznie w przypadku kary za zajęcie pasa drogowego. Mogłoby ono również doprowadzić do kuriozalnej sytuacji, w której jeden zarządca drogi publicznej wydał zezwolenie na zajęcie pasa drogowego, a drugi odmówił. Przepisy prawne nie regulują, w jaki sposób taki spór należy rozwiązać. Z pewnością z pomocą przyszłoby wprowadzenie do systemu prawnego własności warstwowej, jednakże obecnie pozostaje ono w sferze postulatów. 
Dla rozstrzygnięcia sporu należy posłużyć się regułami logicznego rozumowania i uznać, że dla określenia właściwego w sprawie zarządcy drogi decydujące jest, z którą drogą związany jest znajdujący się/mający się znajdować w pasie drogowym obiekt. Warto zwizualizować to przykładem, w którym, jeżeli reklama40 miałaby być widoczna dla uczestników ruchu drogowego drogi innej niż ekspresowa/autostrada, położonej pod drogą ekspresową/autostradą, to wówczas za organ właściwy do rozstrzygnięcia sprawy należałoby uznać prezydenta miasta na prawach powiatu. W przypadku, gdyby taka reklama znalazła się na drodze ekspresowej/ autostradzie - właściwy byłby zarządca tej drogi.

\section{Zakończenie}

Opisane w artykule obowiązki spoczywające na zarządy drogi stanowią jedynie niewielki wycinek kompetencji mu przysługujących. Ze względu na przecinanie się dróg różnej kategorii na obszarze miasta na prawach powiatu przewidziano rozwiązanie, zgodnie z którym na jego obszarze zarządcą wszystkich dróg publicznych, z wyjątkiem autostrad i dróg ekspresowych, jest prezydent miasta. Z tego powodu, dokonując wykładni przepisów u.d.p. wobec prezydenta miasta na prawach powiatu jako zarządcy dróg publicznych, należy dążyć do osiągnięcia spójności i niesprzeczności systemowej. Literalne odczytywanie fragmentu tekstu prawnego nie

Miasto. Pamięć i Przyszłość 3/2 (2018) ISSN 2543-621X

139

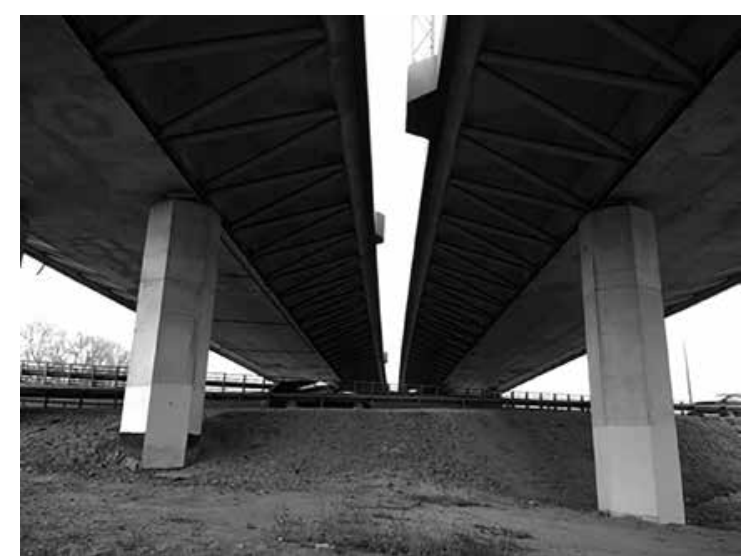

Zdj. 1. Przykład przecinania się autostrady A8 (wyżej) z droga krajowa 94 (niżej) nieopodal Stadionu Miejskiego we Wrocławiu; fot. Pawet Majczak

jest dobrym środkiem do osiągnięcia tego celu, a dosłowne brzmienie przepisu nie jest przekonującym dowodem na zamiar ustawodawcy, jeśli pomija przyjęte przez tego ustawodawcę rozwiązania prawne. Pożądanym uregulowaniem jest wprowadzenie do polskiego systemu prawego własności warstwowej. Dzięki takiemu rozwiązaniu możliwe byłoby uniknięcie sporów o właściwość/kompetencyjnych zachodzących pomiędzy zarządcami dróg różnej kategorii. O ile we Wrocławiu może dojść do sporu kompetencyjnego jedynie między prezydentem miasta a Generalnym Dyrektorem Dróg Krajowych i Autostrad, to w miejscowościach niebędących miastami na prawach powiatu, przez które przebiegają wszystkie kategorie dróg publicznych, do sporu o właściwość/kompetencyjnego może dojść w większej liczbie przypadków.

40. Zgodnie z art. 40 ust. 2 pkt 3 u.d.p. na umieszczenie w pasie drogowym reklam wymagane jest zezwolenie zarządcy drogi. 


\section{Literatura:}

- Administracja publiczna. Ustrój administracji samorządowej, red. B. Szmulik, K. Miaskowska-Daszkiewicz, t. III, Warszawa 2012.

- J. Bujny, Zajęcie pasa drogowego, „Wspólnota” 2010, nr 39.

- A. Chełchowski, Trwaty zarząd nieruchomościami publicznymi, "Samorząd Terytorialny" 2009 nr 3.

- Z. Duniewska, B. Jaworska-Dębska, M. Stahl, Prawo administracyjne materialne, Warszawa 2014.

- D. Felcenloben, Granice nieruchomości i sposoby ich ustalania, Warszawa 2013.

- Z. Janku, Administracyjnoprawna regulacja korzystania z rzeczy powszechnego użytku - na przykładzie dróg publicznych, [w:] Węzłowe problemy materialnego prawa administracyjnego, cz. II, Poznań 2000.

- B. Jaworska-Dębska [w:] Prawo administracyjne. Pojęcia, instytucje, zasady w teorii i orzecznictwie, red. M. Stahl, Warszawa 2013.

- R. Kędziora, Ogólne postępowanie administracyjne, Warszawa 2015.

- J. Korczak, Przekazanie drogi gminnej podmiotowi gospodarczemu, "Nowe Zeszyty Samorządowe” 2016, nr 2.

- W. Kotowski, B. Kurzępa, Drogi publiczne. Komentarz praktyczny, Warszawa 2005.

- K. Kucharski, Zajęcie pasa drogowego w świetle orzecznictwa sądów administracyjnych, „Administracja" 2009, nr 2.

- W. Maciejko, P. Zaborniak, Ustawa o drogach publicznych. Komentarz, Warszawa 2010.

- J. Michalska, Miasto na prawach powiatu - specyficzne połaczenie gminy i powiatu, [w:] Województwo
- region - regionalizacja 15 lat po reformie terytorialnej i administracji. II wydziałowa konferencja kót naukowych Wydziału Prawa, Administracji i Ekonomii Uniwersytetu Wrocławskiego, Wrocław, 21-22 listopada 2013 r., red. Korczak J., Wrocław 2013.

- W. Podhorodecki, Ustawa o drogach publicznych. Orzecznictwo, akty wykonawcze, wzory dokumentów, Warszawa 2013.

- Prawo administracyjne, red. J. Boć, Wrocław 2003.

- S. Rudnicki, Własność nieruchomości, Warszawa 2012.

- I. Sierpowska, Drogi publiczne jako kategoria dobra publicznego - w świetle pogladów doktryny i rozwiqzań normatywnych, http://www.bibliotekacyfrowa. pl/Content/34405/0020.pdf.

- K. Sobieralski, Kara za zajęcie pasa drogowego, Wrocław 2015.

- K. Sobieralski, Zezwolenie na zajęcie pasa drogowego i naliczanie opłat z tego tytułu przed nadaniem drodze stosownej kategorii drogi publicznej, "Nowe Zeszyty Samorządowe" 2015, nr 4.

- M. Stahl, Dobro wspólne w prawie administracyjnym, [w:] Nowe problemy badawcze w teorii prawa administracyjnego, red. J. Boć, A. Chajbowicz, Wrocław 2009.

- R. A. Strachowska, Ustawa o drogach publicznych. Komentarz, Warszawa 2012

- P. Świątecki, Drogi publiczne. Praktyczny komentarz do przepisów prawnych, Zielona Góra 2002.

- B. Wierzbowski, Gospodarka nieruchomościami. Podstawy prawne, Warszawa 2010.

- T. Woś, Wywłaszczenie nieruchomości i ich zwrot, Warszawa 2011. 